\title{
Sleep and Nocturia in Under Age 50 Male Patients with Obstructive Sleep Apnea Syndrome
}

\author{
Yeon Hak Chung ${ }^{1}$, Su Jung Choi ${ }^{1,2}$, Jae Rim Kim ${ }^{1}$, Jaehong Park ${ }^{1}$, Eun Yeon Joo ${ }^{1}$ \\ ${ }^{1}$ Department of Neurology, Neuroscience Center, Samsung Medical Center, Sungkyunkwan University School of Medicine, Seoul, \\ ${ }^{2}$ Department of Nursing, Samsung Medical Center, Department of Clinical Nursing Science, Graduate School of Clinical Nursing Science, \\ Sungkyunkwan University, Seoul, Korea
}

50세 미만 폐쇄수면무호흡증후군 남자 환자에서 수면과 야뇨의 관계

정연학 ${ }^{1}$, 최수정 ${ }^{1,2}$, 김재림1 ${ }^{1}$, 박재홍 ${ }^{1}$, 주은연 ${ }^{1}$

성균관대학교 의과대학 삼성서울병원 신경과, 뇌신경센터, ${ }^{1}$ 성균관대학교 임상간호대학원 삼성서울병원 간호부 ${ }^{2}$

Received May 12, 2020

Revised June 10, 2020

Accepted June 11, 2020

Address for correspondence

Eun Yeon Joo, MD, PhD

Department of Neurology,

Sleep and Epilepsy Section,

Neuroscience Center,

Samsung Medical Center,

Sungkyunkwan University

School of Medicine,

81 Irwon-ro, Gangnam-gu,

Seoul 06351, Korea

Tel: $+82-2-3410-3597$

Fax: +82-2-3410-0052

E-mail: eunyeon.joo@gmail.com
Objectives: To investigate the prevalence of nocturia in young patients with obstructive sleep apnea syndrome (OSAS) and to find out the risk factors of nocturia in the patients. Methods: We enrolled 415 untreated male OSAS patients (apnea-hypopnea index, AHI $\geq 5 / h$ on polysomnography) who were under 50 years old (mean age 37.5 \pm 8.0 years). Participants completed Korean version of Beck depression inventory II (K-BDI-II), Pittsburgh sleep quality index-Korean (PSQI-K), insomnia severity index (ISI), and Epworth sleepiness scale (ESS). Participants were classified into nocturia and non-nocturia group according to the following question "Do you find yourself waking up to urinate more than twice each night?" All information was compared between two groups. Results: $22.7 \%$ (94/415) of patients reported to have nocturia. Patients with nocturia had higher score of K-BDI-II, PSQI-K, ISI, and ESS although their age and the proportion of consumption of alcohol or caffeine and metabolic diseases were not different from patients without nocturia. AHI was not significantly higher in nocturia group $(38.0 \pm 29.2 / \mathrm{h})$ than non-nocturia group $(32.8 \pm 25.7 / \mathrm{h}, p=0.118)$, however, parameters indicating sleep quality were worse in nocturia group, i.e. lesser non-rapid eye movement sleep stage $3(\mathrm{~N} 3)$ sleep \% and higher arousal index, total apnea index, and 90\% oxygen desaturation index (ODI). 90\% ODI and N3 sleep \% were revealed to be independent factors associated with nocturia. Conclusions: Considerable numbers of male OSAS patients who are under 50 years suffer from nocturia and they have worse sleep quality compared to non-nocturia patients. Higher oxygen desaturation and lesser N3 sleep \% are highly predictive factors for nocturia rather than $\mathrm{AHI}$ in these patients.

J Sleep Med 2020;17(1):78-83
서 론

야뇨(nocturia)는 수면 중 1회 이상 소변을 보기 위해 일어 나는 경우로 정의하지만, ${ }^{1}$ 수면 중 2회 이상 소변을 볼 경우 더욱 불편함을 느낀다고 하여, ${ }^{2}$ 임상에서는 2 회 이상의 야간 뇨를 지칭한다. 야뇨는 전체 인구의 $28.5 \%$ 가 겪고 있을 정도

This is an Open Access article distributed under the terms of the Creative Commons Attribution Non-Commercial License (https://creativecommons.org/licenses/by-nc/4.0) which permits unrestricted non-commercial use, distribution, and reproduction in any medium, provided the original work is properly cited.
로 흔하다. ${ }^{3}$ 남녀 모두 연령이 증가함에 따라 야뇨의 비율이 증가하는 것은 동일하나, ${ }^{3} 50$ 세 미만의 $16.5 \%$ 에서 발생하며 여성에서 더 많고, 70 세 이상에서는 $60 \%$ 이상에서 겪게 된 다. ${ }^{3}$ 특히 50 세 이후에서는, 남성의 유병률이 더 높아지는 것 이 특징이다. ${ }^{4,5}$

야뇨는 하부 요로기관 증상(lower urinary tract symptoms) 의 하나로 여겨지며, 그 기전으로는 다뇨증(polyuria), 야간 다뇨증(nocturnal polyuria), 감소된 방광의 용적(reduced bladder capacity), 또는 일차수면장애 및 정신장애(primary 
sleep disorder and psychiatric disorder) 등이 있다. ${ }^{6}$ 그 외 전 립선 질환과 같은 비뇨기계 질환이 있거나, 3,7 심혈관계 질환 혹은 관상동맥질환이 있는 경우, ${ }^{8}$ 이뇨제를 복용할 경우, ${ }^{8}$ 신 장질환, 또는 당뇨에 의하여 야뇨가 발생할 수 있다. ${ }^{3}$ 야뇨에 의한 수면유지장애를 호소하는 환자들의 상당수에서 폐쇄수 면무호흡증후군(obstructive sleep apnea syndrome, OSAS)이 동반되며, OSAS 환자의 약 $50 \%$ 가 야뇨를 겪는다. 910 불면을 호소하는 OSAS 환자들에게 기도양압(positive airway pressure) 치료를 적용한 후 야뇨가 현저하게 줄었다는 보고가 있 는데, ${ }^{11}$ 이는 OSAS가 야뇨를 유발하는 주요한 원인임을 알 수 있다. OSAS에서 야뇨가 호발하는 원인을 생리학적으로 설명하는 여러 기전들이 있다. 수면 중 호흡장애로 인해 흥강 내로 음압이 지속적으로 유지되면 심장으로의 정맥혈이 증 가하여, 혈장과 소변에서 atrial natriuretic peptide(ANP)의 분비가 증가하고 항이뇨호르몬(antidiuretic hormone, $\mathrm{ADH}$ ) 의 분비가 억제되면서 소변 농축이 안 되고 야간 다뇨가 유 발되어 야뇨를 발생시킨다고 설명한다. ${ }^{12}$ 또한 수면호흡장애 로 인한 주기적인 저산소증이 방광의 불안정성을 유발하여 야뇨로 이어진다는 이론도 있는 것으로 보아, ${ }^{13}$ 수면호흡장애 와 야뇨는 매우 밀접한 관계에 있음을 알 수 있다. 단, 수면호 흡장애로 초래되는 다양한 수면 관련 지표 중 야뇨를 예측할 수 있는 값은 아직까지 밝혀져 있지 않다.

본 연구의 가설은 비뇨기과 질환과 같은 야뇨를 초래할 다 른 위험 요인이 배제된 젊은 OSAS 남성 환자의 야뇨가 수면 호흡장애와 동반된 수면의 질과 독립적인 연관성이 있을 것 으로 설정했다. 이에 50세 미만의 남성 OSAS 환자에서의 야 뇨 유병률을 확인하고, 야뇨와 관련된 동반 질환과 수면다원 검사 결과를 분석하여 관련성 있는 수면지표와 야뇨를 예측 할 임상 요인을 찾고자 하였다.

\section{방 법}

\section{대상자}

본 연구는 의무기록을 이용한 후향적 조사로, 2017년 1월 부터 2020년 1월까지 삼성서울병원 수면검사실에 수면다원 검사를 받기 위해 내원한 환자들을 대상으로 했다. 정형화된 설문지를 모두 완성하고 수면다원검사로 확인된 수면 무호 흡-저호흡지수(apnea-hypopnea index, AHI)가 시간당 5회 이상인 50세 미만의 남성 환자를 선별하였다. 야뇨의 유병률 은 성별 간 차이가 크고 위험 요인도 다르기 때문에, 본 연구 에서는 남성으로 한정하여 조사하였다. 50세 이상의 남성은 전립선 용적의 증가로 인한 하부 요로 관련 증상으로 야뇨가 발생할 가능성이 높아서 본 연구에서는 제외하였다. ${ }^{13}$ 그 외
야뇨의 위험인자로 알려진 다음과 같은 질병을 가진 환자 또는 약물을 복용하는 환자는 대상에서 제외하였다: 1) 이뇨 제 복용, 2) 전립선 질환, 3) 조절되지 않은 당뇨(당화혈색소 $6.5 \%$ 이상), 4) 관상동맥질환, 5) 심부전 6) 신장질환.

조사 기간 내 총 1,460 명의 환자가 수면다원검사를 시행하 였고, 이 중 OSAS로 진단받은 50세 미만 남성은 446명이었 다. 이 중 선정 기준에 적합하지 않은 31 명을 제외한 415 명을 최종 대상자로 선정했다. "자다가 2회 이상 화장실에 갑니까?" 라는 설문에 긍정 답변을 한 경우를 야뇨군(nocturia group), 부정 답변을 한 경우는 비야뇨군(non-nocturia group)으로 구 분하였다(Fig. 1).

본 연구에 사용된 연구 기준, 방법 및 평가는 삼성서울병 원 기관윤리심의위원회의 심의(승인번호 2020-04-049)와 동의 면제 승인을 획득하였으며, 기관윤리심의위원회의 관 리감독하에 시행되었다.

\section{설문지}

대상자는 한글판 피츠버그 수면의 질 척도(Pittsburgh sleep quality index-Korean, PSQI-K), ${ }^{14}$ 불면증 심각도지수(insomnia severity index, ISI) ${ }^{15}$ 엡워스 주간졸림증 척도(Epworth sleepiness scale, ESS), ${ }^{16}$ 한국어판 벡 우울척도 II(Korean version of Beck depression inventory II, K-BDI-II)를 작성하였다. ${ }^{17}$ 그 외에 일반적 특성으로 연령, 체질량지수, 생

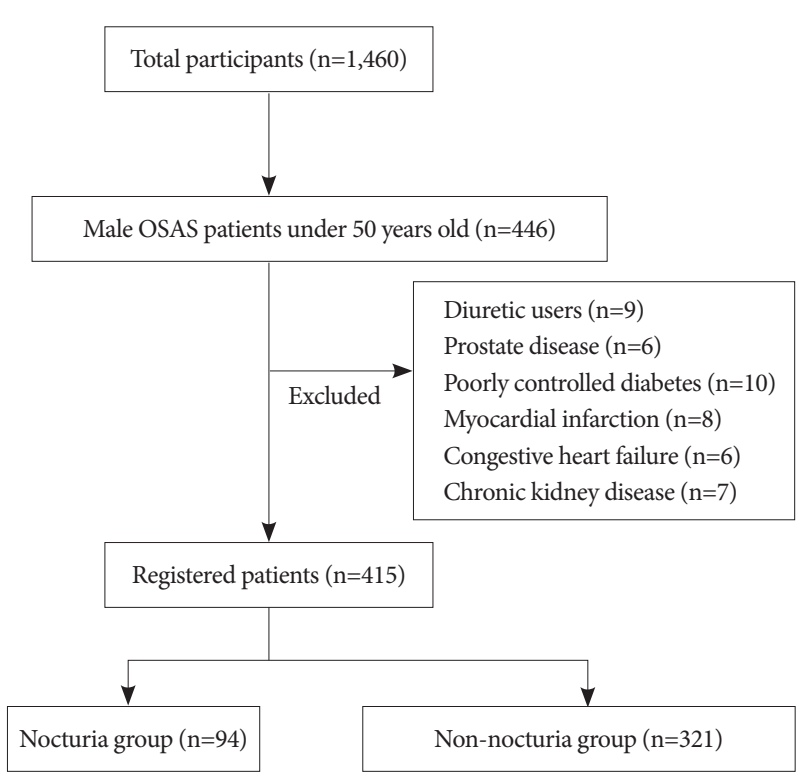

Figure 1. Study flow. We included 446 male OSAS patients under age 50. Patients who were taking diuretics $(n=9)$, or having prostate disease $(n=6)$, poorly controlled diabetes mellitus ( $\mathrm{HbA1c} \geq 6.5 \%$ ) $(n=10)$, myocardial infarction $(n=8)$, congestive heart failure $(n=6)$, or chronic kidney disease $(n=7)$ were excluded. Registered patients were 415 and they were divided into nocturia and non-nocturia groups. OSAS: obstructive sleep apnea syndrome. 
활습관(음주, 흡연, 일 카페인 섭취량), 동반 질환(고혈압, 당 뇨병, 지질이상혈증, 심혈관질환, 신장질환)을 조사하였다.

\section{수면다원검사}

Embla N7000(Medcare Flaga, Reykjavik, Iceland) 장비로 수면검사를 시행했다. 기본 검사 항목으로 6채널의 뇌파(C3$\mathrm{A} 2, \mathrm{C} 4-\mathrm{A} 1, \mathrm{~F} 3-\mathrm{A} 2, \mathrm{~F} 4-\mathrm{A} 1, \mathrm{O} 1-\mathrm{A} 2, \mathrm{O} 2-\mathrm{A} 1$ )와 4채널의 안 전위도(electro-oculogram), 1채널의 턱근전도(chin electromyography)를 기록하여 수면의 단계와 각성 빈도를 측정하 였다. 호흡 관련 측정을 위해서 압력 센서를 이용하여 비강 공기압을 측정하였다. 호흡 노력을 보기 위해 흥곽과 복부 벨트를 이용하여 호흡 움직임을 측정하였다. Oximetry를 이 용하여 검지손가락에서 산소포화도를 측정하였고, 소리 센 서로 코골이 강도를 측정하였다. 다리 움직임을 보기 위해 2 채널의 양측 전경골근(anterior tibialis)의 근전도를 측정하였 다. 수면 자세를 확인하는 체위 센서와 심전도를 함께 측정 하며 동시에 비디오를 기록하여 수면 중 행동장애나 자세를 기록하였다.

수면단계와 호흡지수 등 수면다원검사 평가는 American Academy of Sleep Medicine(AASM) Manual에 따라 판독했 다. ${ }^{18}$ 수면구조는 뇌파, 근전도, 안구 움직임 등을 통해 수면 단 계를 분석한 것으로, non-rapid eye movement(REM) sleep stage 1(N1), non-REM sleep stage 2(N2), non-REM sleep stage 3(N3), REM 수면의 비율로 조사하였다. 수면 양상은 수면 잠복기(sleep latency), 입면 후 각성시간(wakefulness after sleep onset, WASO), 총 수면시간(total sleep time), 수면 효 율(sleep efficiency)로 측정하였고, 각성지수(arousal index) 등을 평가하였다. 무호흡(apnea)은 10초 이상 호흡이 멈추는 것으로 비강의 온도와 압력 센서를 통해 공기 흐름이 $90 \%$ 이 상 감소하는 상태를 말하며, 호흡저하(hypopnea)는 공기 흐 름이 10 초 이상 $30 \%$ 이상 감소를 보이면서 산소포화도가 $4 \%$ 이상 떨어지는 경우 또는 뇌파상 각성이 관찰되는 경우로 정 의하였다. 무호흡-저호흡지수(AHI)가 시간당 5 회 이상이면 서 주간졸림, 피로 등 주간 증상 또는 수면무호흡, 코골이가 있는 경우에 OSAS로 진단하였다. ${ }^{19}$

\section{통계 분석}

대상자의 특성과 수면다원검사 결과는 평균과 표준편차, 빈도와 백분율로 기술하였다. 야뇨군과 비야뇨군 간의 차이 는 t-test 또는 카이제곱 검정을 시행하였다. 야뇨 관련 요인 을 파악하기 위해서 비교 검정에서 유의한 차이를 보이는 변 수 및 선행연구에서 유의한 차이가 있다고 밝혀진 변수들에 대해 단변량 로지스틱회귀분석을 시행하였고, $p$ 값 0.20 에서
유의한 변수에 대하여 다변량 로지스틱회귀분석을 진행하였 다. 통계 분석은 SPSS 25.0(IBM Corp., Armonk, NY, USA) 를 이용하였으며, $p$ 값이 0.05 미만인 경우 통계적으로 유의 미한 것으로 판단하였다.

\section{결 과}

분석을 시행한 415 명의 환자 중 94명(22.7\%)은 야뇨군, 321명(77.3\%)은 비야뇨군으로 분류되었다.

\section{대상자 특성}

야뇨군의 평균 연령(38.8 \pm 7.1 세 vs. $37.2 \pm 8.3$ 세)과 체질량 지수(body mass index, $28.4 \pm 4.4 \mathrm{~kg} / \mathrm{m}^{2}$ vs. $27.7 \pm 4.1 \mathrm{~kg} / \mathrm{m}^{2}$ ) 는 비야뇨군과 유의한 차이가 없었다 $(p>0.05)$. 음주량, 흡연 량, 카페인 섭취량도 두 군 간 차이가 없었으며, 기저질환도 유의한 차이를 보이지 않았다. 야뇨군은 주관적인 수면의 질을 더 나쁘게 평가했고(PSQI-K, $8.1 \pm 3.5$ vs. 6.6 $\pm 3.0 ; p<0.001$ ), 불면 관련 증상을 더 심하게 호소했다(ISI, $12.5 \pm 5.1$ vs. $9.0 \pm$ $5.2 ; p<0.001)$. 주간졸음과 우울감도 야뇨군에서 유의하게 더 높았다(Table 1).

\section{수면지표 비교}

야뇨군과 비야뇨군 간의 $\mathrm{AHI}(38.0 \pm 29.2 / \mathrm{h}$ vs. $32.8 \pm 25.7 / \mathrm{h}$; $p=0.118$ )는 차이가 없었으나, 무호흡지수(apnea index)는 야

Table 1. Subject characteristics between nocturia and non-nocturia groups with obstructive sleep apnea syndrome

\begin{tabular}{lccc}
\hline \multicolumn{1}{c}{ Characteristics } & $\begin{array}{c}\text { Nocturia } \\
(\mathrm{n}=94)\end{array}$ & $\begin{array}{c}\text { Non-nocturia } \\
(\mathrm{n}=321)\end{array}$ & $p$ \\
\hline Age (years) & $38.8 \pm 7.1$ & $37.2 \pm 8.3$ & 0.057 \\
Body mass index $\left(\mathrm{kg} / \mathrm{m}^{2}\right)$ & $28.4 \pm 4.4$ & $27.7 \pm 4.1$ & 0.120 \\
Alcohol (g/week) & $107.3 \pm 189.1$ & $110.1 \pm 261.9$ & 0.925 \\
Smoking (pack-year) & $4.1 \pm 8.8$ & $3.1 \pm 6.6$ & 0.295 \\
Caffeine (cups/day) & $2.0 \pm 1.8$ & $1.7 \pm 1.2$ & 0.199 \\
Hypertension (\%) & $28.7(27)$ & $21.8(70)$ & 0.163 \\
Diabetes mellitus (\%)* & $6.4(6)$ & $3.7(12)$ & 0.259 \\
Dyslipidemia (\%) & $11.7(11)$ & $14.6(47)$ & 0.470 \\
PSQI-K & $8.1 \pm 3.5$ & $6.6 \pm 3.0$ & $<0.001$ \\
ISI & $12.5 \pm 5.1$ & $9.0 \pm 5.2$ & $<0.001$ \\
ESS & $11.6 \pm 4.8$ & $10.3 \pm 4.3$ & 0.013 \\
K-BDI-II & $14.4 \pm 9.7$ & $10.7 \pm 7.5$ & 0.001 \\
\hline
\end{tabular}

Values are expressed as mean \pm standard deviation or column $\%$ (numbers). *only controlled diabetes mellitus was included (HbA1c $<6.5 \%)$. PSQI-K: Pittsburg sleep quality index-Korean, ISI: insomnia severity index, ESS: Epworth sleep scale, K-BDI II: Korean version of Beck depression inventory II 
뇨군에서 유의하게 높았다(21.4 $\pm 27.9 / \mathrm{h}$ vs. $14.8 \pm 22.2 / \mathrm{h} ; p=$ 0.037). 수면 단계는 야뇨군에서 N3 수면 \%가 유의하게 감소 했다(4.6 $\pm 5.9 \%$ vs. $6.8 \pm 7.2 \% ; p=0.003)$.

비야뇨군와 비교하여 야뇨군의 각성지수가 더 높았고 (31.9 $\pm 19.9 / \mathrm{h}$ vs. $27.5 \pm 17.6 / \mathrm{h} ; p=0.041), 90 \%$ 산소불포화 도지수[90\% oxygen desaturation index(90\% ODI), 18.3 \pm $26.4 / \mathrm{h}$ vs. $10.9 \pm 20.2 / \mathrm{h} ; p=0.013] 90 \%$ 이하 산소포화도 시 간 \%[below $90 \%$ oxygen saturation $\left(\mathrm{SaO}_{2}\right)$ ]가 더 높게 관찰 되었다 $(9.4 \pm 17.6 \%$ vs. $5.4 \pm 12.4 \% ; p=0.038)$. 이는 수면 중 $90 \%$ 이상의 산소포화도에 도달하는 횟수와 시간이 모두 증 가된 것을 뜻한다. 수면시간과 수면 효율, 수면 중 깨어 있는

Table 2. Polysomnography parameters between nocturia and non-nocturia groups with obstructive sleep apnea syndrome

\begin{tabular}{|c|c|c|c|}
\hline Variables & $\begin{array}{c}\text { Nocturia } \\
(\mathrm{n}=94)\end{array}$ & $\begin{array}{c}\text { Non- } \\
\text { nocturia } \\
(\mathrm{n}=321)\end{array}$ & $p$ \\
\hline Total sleep time (min) & $366.0 \pm 59.2$ & $371.7 \pm 59.8$ & 0.414 \\
\hline Sleep latency (min) & $8.6 \pm 13.1$ & $9.9 \pm 13.7$ & 0.567 \\
\hline REM latency (min) & $103.0 \pm 67.6$ & $100.6 \pm 53.3$ & 0.747 \\
\hline WASO (\%) & $11.7 \pm 9.5$ & $11.3 \pm 9.0$ & 0.704 \\
\hline Sleep efficiency (\%) & $86.6 \pm 10.4$ & $86.8 \pm 10.2$ & 0.883 \\
\hline \multicolumn{4}{|l|}{ Sleep stage (\%) } \\
\hline N1 sleep & $22.7 \pm 12.6$ & $21.3 \pm 13.0$ & 0.349 \\
\hline N2 sleep & $53.6 \pm 11.1$ & $52.6 \pm 11.1$ & 0.429 \\
\hline N3 sleep & $4.6 \pm 5.9$ & $6.8 \pm 7.2$ & 0.003 \\
\hline REM sleep & $19.1 \pm 7.0$ & $19.3 \pm 6.2$ & 0.719 \\
\hline AHI (events/h) & $38.0 \pm 29.2$ & $32.8 \pm 25.7$ & 0.118 \\
\hline Apnea index & $21.4 \pm 27.9$ & $14.8 \pm 22.2$ & 0.037 \\
\hline Hypopnea index & $16.6 \pm 11.9$ & $18.0 \pm 12.2$ & 0.341 \\
\hline Arousal index (events/h) & $31.9 \pm 19.9$ & $27.5 \pm 17.6$ & 0.041 \\
\hline Respiratory & $25.6 \pm 23.1$ & $20.4 \pm 19.5$ & 0.052 \\
\hline RERA & $2.1 \pm 2.2$ & $2.4 \pm 2.3$ & 0.335 \\
\hline Snoring & $0.7 \pm 1.3$ & $0.7 \pm 1.0$ & 0.829 \\
\hline Spontaneous & $3.0 \pm 3.4$ & $3.7 \pm 3.6$ & 0.112 \\
\hline Movement-related & $0.5 \pm 1.3$ & $0.3 \pm 0.9$ & 0.262 \\
\hline PLM index (events/h) & $17.5 \pm 21.6$ & $9.5 \pm 11.7$ & 0.066 \\
\hline Lowest $\mathrm{SaO}_{2}(\%)$ & $80.6 \pm 9.3$ & $82.0 \pm 9.2$ & 0.192 \\
\hline Below $90 \% \mathrm{SaO}_{2}(\%)$ & $9.4 \pm 17.6$ & $5.4 \pm 12.4$ & 0.038 \\
\hline 90\% ODI (events/h) & $18.3 \pm 26.4$ & $10.9 \pm 20.2$ & 0.013 \\
\hline
\end{tabular}

Values are expressed as mean \pm standard deviation. REM: rapid eye movement, WASO: wakefulness after sleep onset, N1: non-REM sleep stage 1, N2: non-REM sleep stage 2, N3: non-REM sleep stage 3, AHI: apnea-hypopnea index, RERA: respiratory effort related arousal, PLM: periodic limb movement, $\mathrm{SaO}_{2}$ : oxygen saturation, below $90 \% \mathrm{SaO}_{2}$ : percentage of estimated sleep time below $90 \%$ $\mathrm{SaO}_{2}, 90 \%$ ODI: $90 \%$ oxygen desaturation index (the number of oxygen desaturations below $90 \%$ per hour of estimated sleep time)
시간(WASO)은 두 군 간 유의한 차이가 없었다(Table 2).

\section{야뇨의 예측인자}

야뇨군과 비야뇨군 간 유의한 차이를 보인 지표를 확인하 였고 선행논문에서 유의한 차이가 있다고 알려진 인자들에 대해 단변량 로지스틱회귀분석을 시행하였다. 나이, 고혈압, 당뇨병, N3 수면 \%, AHI, 무호흡지수(apnea index), 각성지수 (arousal index), 90\% ODI, below $90 \% \mathrm{SaO}_{2}$ 를 변수에 포함시 켰다. 두 군 간 유의한 차이를 보였던 PSQI-K, ISI, K-BDIII 의 설문지 점수는 야뇨의 원인이 아닌 결과로 추정하여 분 석에 포함시키지 않았다. 단변량 로지스틱회귀분석에서는 $\mathrm{N} 3$ 수면 \%, 무호흡지수, 각성지수 및 산소포화도 관련 지수 (below $90 \% \mathrm{SaO}_{2}, 90 \% \mathrm{ODI}$ )가 유의한 변수로 관찰되었다 (Table 3).

단변량 분석에서 유의한 변수로 나타난 값으로 다변량 로 지스틱회귀분석을 시행한 결과, $90 \%$ ODI(odds ratio=1.011, 95\% confidence interval=1.001 1.021)와 N3 수면 \%(0.960, 0.923 0.998)가 독립적인 위험인자로 확인되었다. 즉, 50세 미만의 남성 OSAS 환자에서 야뇨의 위험도는 산소포화도가 $90 \%$ 미만으로 떨어지는 시간당 사건의 1.011 배 증가하며, N3

Table 3. Logistic regression analysis for factors related to nocturia

\begin{tabular}{lcc}
\hline \multicolumn{1}{c}{ Risk factors } & Odds ratio (95\% CI) & $p$ \\
\hline Age (years) & $1.027(0.997-1.058)$ & 0.079 \\
Hypertension & $1.445(0.860-2.429)$ & 0.165 \\
Diabetes mellitus* & $1.756(0.641-4.812)$ & 1.756 \\
$\mathrm{~N} 3$ sleep (\%) & $0.950(0.914-0.987)$ & 0.008 \\
AHI (events/h) & $1.007(0.999-1.016)$ & 0.093 \\
Apnea index (events/h) & $1.011(1.002-1.020)$ & 0.019 \\
Arousal index (events/h) & $1.012(1.000-1.024)$ & 0.043 \\
Lowest $\mathrm{SaO}_{2}(\%)$ & $0.984(0.961-1.008)$ & 0.193 \\
Below 90\% SaO $(\%)$ & $1.018(1.004-1.034)$ & 0.015 \\
90\% ODI (events/h) & $1.109(1.020-1.207)$ & 0.016 \\
\hline
\end{tabular}

*only controlled diabetes mellitus was included (HbA1c $<6.5 \%)$. N3: non-rapid eye movement sleep stage 3, AHI: apnea-hypopnea index, $\mathrm{SaO}_{2}$ : oxygen saturation, below $90 \% \mathrm{SaO}_{2}$ : percentage of estimated sleep time below $90 \% \mathrm{SaO}_{2}, 90 \%$ ODI: $90 \%$ oxygen desaturation index (the number of oxygen desaturations below $90 \%$ per hour of estimated sleep time), CI: confidence interval

Table 4. Multivariate logistic regression analysis for factors related to nocturia

\begin{tabular}{lcc}
\hline \multicolumn{1}{c}{ Risk factors } & Odds ratio (95\% CI) & $p$ \\
\hline 90\% ODI (events/h) & $1.011(1.001-1.021)$ & 0.034 \\
N3 sleep (\%) & $0.960(0.923-0.998)$ & 0.040 \\
\hline
\end{tabular}

90\% ODI: $90 \%$ oxygen desaturation index (the number of oxygen desaturations below $90 \%$ per hour of estimated sleep time), N3: non-rapid eye movement sleep stage 3 , CI: confidence interval 
수면 \%가 $1 \%$ 증가할 때마다 0.960배 감소하였다(Table 4).

\section{고 찰}

OSAS 환자에서 야간다뇨증이 흔하고, 희석된 야간뇨가 흔하게 동반된다. ${ }^{20}$ 수면호흡장애와 야뇨의 밀접한 관련성은 주지의 사실이나, 수면 및 호흡 관련 지표 중 야뇨와 관련되어 있고 야뇨를 예측할 수 있는 지표는 아직까지는 잘 알려져 있지 않다. 야뇨를 유발하는 기저질환이나 약물은 매우 많기 때문에, 수면호흡장애 자체의 영향을 분석하기 위해서는 비 뇨기계 질환의 유병률이 비교적 낮은 50세 미만의 젊은 환자 들을 대상으로 하였으며, 성별에 따른 야뇨의 원인과 유병률 도 매우 달라서, 본 연구에서는 남성 환자만을 모아서 분석 을 했다. 수면다원검사 전 작성하는 설문지에 포함된 질문은 “자다가 2회 이상 화장실에 갑니까?”로 야뇨군과 비야뇨군 으로 구분하였으며, 본 질문에는 시간적 개념이 포함되지는 않는다. PSQI-K, ISI, ESS 등의 수면 관련 설문은 작성 시점 을 기준하여 지난 한 달간의 상태를 표현하도록 되어 있다. 그런데 수면, 졸림, 불면과 같이 야뇨도 증상과 빈도의 변동 성이 크기 때문에, 환자들은 자가 평가를 통해 지난 기간 동 안의 평균치를 내어 작성하는 것을 어려워한다. 따라서 본 연 구에서는 검사 수행 이전 수일 동안에 2 회 이상의 야뇨로 인 한 수면장애가 있는지를 질문하여 수면다원검사 시점의 상황 을 좀 더 정확히 나타내고자 하였다. 지난 3년간 본원에서 OSAS로 진단받은 50세 미만의 남성 중 2회 이상의 야뇨를 호소하는 사람은 23\%로, 유사한 타 연구(27 48\%)에 비해 약 간 낮았다. $10,21,22$ 타 연구들은 본 연구와 달리 모집군의 연령 제한이 없었고(19 83 y), 야뇨에 직접적인 영향을 줄 수 있 는 당뇨, 심장질환 등과 같은 기저질환자의 배제도 없었기 때문에, 더 높은 유병률을 나타냈을 것으로 추정한다. 야뇨 에 대한 수면호흡장애 단독 효과를 확인했다는 점이 본 연구 의 강점으로 생각된다.

야뇨군과 비야뇨군 간에 차이를 보였던 수면다원검사지표 는 N3 수면 \%, 무호흡지수(apnea index), 각성지수(arousal index), 및 90\% ODI로 나타났다. AHI 값 자체는 두 군 간 차 이가 없었지만 야뇨군에서 무호흡 횟수가 더 많고, 더 자주 깨고, $90 \%$ 이하로 산소포화도가 떨어지는 횟수가 더 많고, 깊 은 잠인 N3 수면 \%가 더 낮았다는 점은 OSAS 진단 기준상 의 심각도는 같으나 야뇨군에서 각각의 수면다원검사상 지 표에서 악화된 소견이 관찰된다. 특히 다변량 로지스틱회귀 분석에서 $90 \% \mathrm{ODI}$ 와 N3 수면 \%가 야뇨와 밀접한 관련성이 있었다.

2008년 Moriyama 등은 50대 이하 73명 남성에서 AHI가
높을수록 야뇨가 증가했다고 보고했다. ${ }^{21}$ Moriyama 등은 호 흡 감소와 동반된 3\% 이상의 산소포화도 감소만을 저호흡으 로 정의하였고, ${ }^{21}$ 이는 산소포화도의 감소 없이 호흡 감소와 연관된 각성은 $\mathrm{AHI}$ 값에서 배제가 된 상황이다. 반면 본 연 구에서는 2013년 개정된 AASM scoring에 따라 저호흡(hypopnea)의 범주에 호흡 감소와 동반된 산소포화도 저하뿐만 아니라, ${ }^{22}$ 호흡 감소와 연관된 각성도 포함하고 있다. 본 연구 에서 $\mathrm{AHI}$ 와 hypopnea index는 야뇨군과 비야뇨군 간에 차 이도 없었으나, apnea index에서는 두 군 간에 유의한 차이 가 관찰되었다. AHI 및 hypopnea index는 hypopnea 정의 상 산소포화도의 저하 없이 발생한 호흡 감소와 연관된 각 성이 포함되어 있다. Apnea index는 90\% 이상의 공기 흐름 이 감소된 상황만 포함시키고 각성의 동반은 고려하지 않는 다. AHI 및 hyponea index에서 차이가 없고 apnea index에 서만 유의한 차이가 있다면, 이는 이 환자군에서의 야뇨는 호흡장애로 인한 각성보다는 저산소증과 더 연관성이 있음 을 시사한다.

2009년 Chung 등은 304명의 환자에서 수면다원검사상 저산소증(hypoxia)과 연관된 지표인 평균 산소포화도(mean $\mathrm{SaO}_{2}$ )와 3\% 및 4\% 산소불포화도지수(3\%/4\% ODI)가 OSAS 환자에서의 야뇨에 유의하게 영향을 주는 변수로 보고하 여, ${ }^{23}$ 본 연구와 유사점을 보였다. 다만 해당 연구에서 야뇨군 (55.46세)과 비야뇨군(45.49세)의 평균 연령이 본 연구의 대 상자보다 높았고 여성을 포함시켰으며(남자 221명, 여자 83 명), 야뇨에 영향을 준다고 알려진 다른 임상 요인(심혈관질 환, 신장질환, 이뇨제 복용 등)에 대한 정확한 조사가 되지 않아서 해석에 제한이 있다.

수면 단계 중 N3 수면 \%만이 두 군 간 차이를 보였고, 야 뇨의 독립적인 위험인자로 확인되었다. 깊은 잠의 감소는 야 뇨의 원인일 수도 있고 결과일 수도 있다. 야뇨군의 AHI가 비야뇨군보다 더 높지 않았음에도 불구하고 각성지수가 유 의하게 높았다는 것은 깊은 잠에 접어들게 하는 기회가 더 적었음을 의미한다. 결국 깊은 잠이 감소하면, 주관적으로 수면의 질을 낮게 평가하고 불면 관련 호소를 더 많이 하게 된다. 수면의 질과 우울증과 같은 감정장애는 밀접한 관련성 이 있다. ${ }^{24}$ 따라서 본 연구에서 관찰된 야뇨군의 유의한 특성 (불면과 우울 지수가 높음)은 모두 불량한 수면의 지표와 연 관된 것으로 해석될 수 있다

본 연구의 제한점은 다음과 같다. 첫 번째, 단면연구(crosssectional study)의 한계로 인해 야뇨와 관련 지표 간의 인과 관계를 밝히지는 못했다. 두 번째, 야뇨의 기전에 관여한다고 알려진 호르몬 수치(ANP, ADH)를 측정하지 않았다. 세 번 째, 낮 동안의 하부 요로기관 증상에 대한 설문이나 방광 기 
능에 대한 평가를 시행하지 않았다. 그럼에도 불구하고 본 연 구에서는 50세 미만의 젊은 남성들에서 OSAS로 인한 야뇨의 유병률을 국내 처음으로 밝혔으며 저산소증 연관 지표인 $90 \%$ ODI와 깊은 잠의 감소가 야뇨의 독립적인 위험인자임을 확인했다. 본 연구 결과를 기반으로, 50 세 미만의 남성 OSAS 환자에서 저산소증이 심할 경우 야뇨 증상의 확인이 필요함 을 제언하는 바이다.

\section{Acknowledgments}

This study is granted by Samsung Biomedical Research Institute grant (OTC1190671).

\section{Conflicts of Interest}

The authors have no potential conflicts of interest to disclose.

\section{ORCID iDs}

Yeon Hak Chung

Su Jung Choi

Jae Rim Kim

Jaehong Park

Eun Yeon Joo https://orcid.org/0000-0002-7052-2432

https://orcid.org/0000-0003-2171-7441

https://orcid.org/0000-0002-3404-199X

https://orcid.org/0000-0001-7247-4932

https://orcid.org/0000-0003-1233-959X

\section{Author Contributions}

Conceptualization: Eun Yeon Joo, Yeon Hak Chung. Data curation: Yeon Hak Chung, Jae Rim Kim, Jaehong Park. Formal analysis: Yeon Hak Chung. Investigation: Yeon Hak Chung. Methodology: Yeon Hak Chung, Eun Yeon Joo, Su Jung Choi. Supervision: Eun Yeon Joo, Su Jung Choi. Writing_original draft: Yeon Hak Chung. Writing_review \& editing: Eun Yeon Joo, Su Jung Choi, Yeon Hak Chung.

\section{REFERENCES}

1. van Kerrebroeck P, Abrams P, Chaikin D, et al. The standardisation of terminology in nocturia: report from the Standardisation Sub-committee of the International Continence Society. Neurourol Urodyn 2002; 21:179-183.

2. Tikkinen KA, Johnson TM 2nd, Tammela TL, et al. Nocturia frequency, bother, and quality of life: how often is too often? A populationbased study in Finland. Eur Urol 2010;57:488-496.

3. Yoshimura K, Terada N, Matsui Y, Terai A, Kinukawa N, Arai Y. Prevalence of and risk factors for nocturia: analysis of a health screening program. Int J Urol 2004;11:282-287.

4. Tikkinen KAO, Tammela TLJ, Huhtala H, Auvinen A. Is nocturia equally common among men and women? A population based study in finland. J Urol 2006;175:596-600.

5. Yoshimura K. Correlates for nocturia: a review of epidemiological studies. Int J Urol 2012;19:317-329.

6. Cornu JN, Abrams P, Chapple CR, et al. A contemporary assessment of nocturia: definition, epidemiology, pathophysiology, and management-A systematic review and meta-analysis. Eur Urol 2012;62:877-890.

7. Hsu CY, Iribarren C, McCulloch CE, Darbinian J, Go AS. Risk factors for end-stage renal disease: 25-year follow-up. Arch Intern Med 2009; 169:342-350.

8. Fitzgerald MP, Litman HJ, Link CL, McKinlay JB, Investigators BS. The association of nocturia with cardiac disease, diabetes, body mass index, age and diuretic use: results from the BACH survey. J Urol 2007; 177:1385-1389.

9. Oztura I, Kaynak D, Kaynak HC. Nocturia in sleep-disordered breathing. Sleep Med 2006;7:362-367.

10. Hajduk IA, Strollo PJ Jr., Jasani RR, Atwood CW Jr., Houck PR, Sanders MH. Prevalence and predictors of nocturia in obstructive sleep apnea-hypopnea syndrome--A retrospective study. Sleep 2003;26:61-64.

11. Margel D, Shochat T, Getzler O, Livne PM, Pillar G. Continuous positive airway pressure reduces nocturia in patients with obstructive sleep apnea. Urology 2006;67:974-977.

12. Umlauf MG, Chasens ER. Sleep disordered breathing and nocturnal polyuria: nocturia and enuresis. Sleep Med Rev 2003;7:403-411.

13. Berry SJ, Coffey DS, Walsh PC, Ewing LL. The development of human benign prostatic hyperplasia with age. J Urol 1984;132:474-479.

14. Sohn SI, Kim DH, Lee MY, Cho YW. The reliability and validity of the Korean version of the Pittsburgh sleep quality index. Sleep Breath 2012; 16:803-812.

15. Cho YW, Song ML, Morin CM. Validation of a Korean version of the insomnia severity index. J Clin Neurol 2014;10:210-215.

16. Cho YW, Lee JH, Son HK, Lee SH, Shin C, Johns MW. The reliability and validity of the Korean version of the Epworth sleepiness scale. Sleep Breath 2011;15:377-384.

17. Sung HM, Kim JB, Park YN, Bai DS, Lee SH, Ahn HN. A study on the reliability and the validity of Korean version of the Beck depression inventory-II (BDI-II). J Korean Soc Biol Ther Psychiatry 2008;14:201-212.

18. Berry RB, Brooks R, Gamaldo C, et al. AASM scoring manual updates for 2017 (version 2.4). J Clin Sleep Med 2017;13:665-666.

19. Sateia MJ. International classification of sleep disorders-third edition: highlights and modifications. Chest 2014;146:1387-1394.

20. Lowenstein L, Kenton K, Brubaker L, et al. The relationship between obstructive sleep apnea, nocturia, and daytime overactive bladder syndrome in women. Am J Obstet Gynecol 2008;198:598.e1-e5.

21. Moriyama Y, Miwa K, Tanaka H, Fujihiro S, Nishino Y, Deguchi T. Nocturia in men less than 50 years of age may be associated with obstructive sleep apnea syndrome. Urology 2008;71:1096-1098.

22. Shamim-Uzzaman QA, Singh S, Chowdhuri S. Hypopnea definitions, determinants and dilemmas: a focused review. Sleep Science and Practice 2018;2:7.

23. Chung JH, Moon HS, Park SY, Kim KR, Cho SH, Kim YT. Effect of nocturnal hypoxia on nocturia in patients with obstructive sleep apnea. Int Neurourol J 2019;23:161-168.

24. O'Leary K, Bylsma LM, Rottenberg J. Why might poor sleep quality lead to depression? A role for emotion regulation. Cogn Emot 2017;31: 1698-1706. 